\title{
An "Other" Social Mobility, Viewed from the Standpoint of Exclusion
}

\author{
Ricardo Cuenca ${ }^{\mathrm{a}, *}$ \\ ${ }^{a}$ Institute of Peruvian Studies, Peru
}

\begin{abstract}
The purpose of this article is to analyze how social mobility and social inclusion are perceived by a group of professionals from modest backgrounds, who graduated from public universities and whose personal histories reflect levels of exclusion. This qualitative study, which is organized in six dimensions of analysis - migration and territorial mobility, education, occupation and income, social capital, vulnerability, and expectations-shows four main findings, which inevitably also raise new working hypotheses. The findings are the following: that social mobility and social inclusion are heterogeneous processes that education remains a means of both mobility and inclusion, that social mobility coexists with inequality, and that mobility and social inclusion require broader means of conceptualization because of the difficulty of understanding this process in people with particular characteristics and from particular backgrounds.
\end{abstract}

\begin{abstract}
Abstrak
Tujuan makalah ini adalah menganalisa mobilitas dan inklusi sosial yang dirasakan oleh kelompok professional berlatar belakang menengah/sederhana, lulusan universitas negeri, dan pernah terpingginggirkan dalam sejarah hidupnya. Studi kualitatif ini, yang dikelompokkan dalam enam dimensi analisis - migrasi dan mobilitas territorial, pendidikan, pekerjaan dan pendapatan, kapital sosial, kerentanan dan ekpektasi-menunjukkan empat temuan utama yang memunculkan hipotesis baru. Temuan tersebut adalah: bahwa mobilitas dan inklusi sosial merupakan proses heterogen, bahwa pendidikan tetap menjadi alat penunjang mobilitas dan inklusi, bahwa mobilitas sosial bersandingan dengan ketidaksetaraan, dan bahwa mobilitas dan inklusi sosial memerlukan ikhtisar konsep yang lebih luas karena sulitnya memahami proses ini pada kelompok individu dengan karakter dan latar belakang tertentu.
\end{abstract}

Key Words: Social Mobility, Social Inclusion, Exclusion, Higher Education, Inequality

\section{Introduction}

The most important international studies of social mobility show that changes in the industrial apparatus and migration from the countryside to the city are the most important elements for studying the topic (for more information, see the assessments by Nunn, Johnson, Monro, Bickerstaffe and Kelsey 2007, Atria 2007 and Crompton 1994). Factors such as occupation and income of parents and children have therefore been considered to determine whether they actually led to upward or downward social mobility. Studies in the second half of the twentieth century (Lipset and Bendix 1959, Glass 1963, Blau and Duncan 1967) found that social groups in the United States and Great Britain were in transition

* Corresponding author. Address: Horacio Urteaga 694, Jesús María, Lima 15072, Perú. Email: rcuenca@iep.org.pe. toward higher rungs of the social ladder after World War II. Because this assumed that rates of absolute mobility in those countries were increasing, discussion focused on determining why individual mobility is more limited and the reasons why a person from a lower class can ascend to the middle class. This debate has become significant again, particularly in Peru, now that studies of inequality have detected the high levels of complexity implied by this phenomenon, which is so persistent in the country (Cotler and Cuenca 2011, Thorp and Paredes 2011, León and Iguíniz 2011). This is illustrated by the reflections of one of the participants from the study:

I feel as though I am battling hard to be the subject, the actor. The scholarship system has enabled me to be included. But within that circle of inclusion, I kick a lot. It's not like they open the door and I say, "Great! Now I'm a student at the 
Catholic University." I struggle every day at the door. I struggle every day with my professor, with my professors, with my classmates. (E-04)

The purpose of this article is to understand how social mobility and social inclusion are perceived by a group of professionals who were part of the Ford Foundation International Fellowships Program (IFP). These are individuals who come from modest backgrounds, who graduated from public universities and whose personal histories reflect levels of exclusion. We then ask whether the initial state of exclusion in which these people found themselves changed as a result of their graduate studies, what factors helped or hindered their social mobility, and what relationship exists among education, mobility and inclusion.

\section{Research Methods}

A qualitative methodological approach was used for this study. This approach responded to the demands of the task, as it sought to reconstruct in detail the mobility and inclusion of a group of professionals from different subaltern groups. There were two working hypotheses. First, we maintain that professionals from traditionally excluded groups experience mobility and inclusion in particular ways, and that the use of standard elements is therefore inadequate for understanding these processes. Second, we propose that, despite structural barriers, education is a direct route to social mobility and social inclusion, especially when offered to subaltern groups.

The information was analyzed on two levels. The quantitative analysis used data from a database constructed with information from 180 files of a group of professionals (to whom we will refer hereafter as "fellows") from traditionally excluded populations who were part of the IFP. The profile of the Peruvian IFP fellows is mainly male (57 percent), with an average age of 35 (at the time of graduate studies); 51 percent speak Spanish as their first language, and in 41 percent of the cases, their parents are peasant farmers. Peruvian fellows had spent their lives in public education (more than 90 percent) and had a monthly income of between 701 and 1,300 soles. To supplement the "hard" information from the IFP fellow profile, qualitative characteristics can be identified, organized around a triad consisting of the state of exclusion, leadership and social commitment, and academic potential (Cuenca and Niño 2011). These data included socio-demographic, economic, cultural and education variables. For the qualitative analysis, information from 15 semi-structured interviews and a focus group with the IFP fellows was studied. For a contrasting view of the study problem, four focus groups were organized with graduates of various graduate programs whose characteristics differed from those of the IFP fellows.

We understand that for the fellows, success translates into the possibility of meeting material needs without pressure and attaining a "decent life," as well as in achieving personal goals that also reflect a commitment to their communities. We hope that this information contributes to a contextualized understanding of higher education and its connection with social mobility and social inclusion, and that it also offers ideas for enhancing social justice.

\section{Literature Review}

\section{Social Mobility from the Standpoint of Exclusion: Initial Outcomes}

There are still few studies of social mobility in our country. Nevertheless, there have been some valuable efforts at reflection, as we discuss below.

One of the first books on the subject was published by Carlos Delgado (1967), who analyzed social mobility in Peru in the late 1960s. He believed there were seven mechanisms for social mobility: the educational system, the public administration system, the extra-political institutional network, residential settlement patterns, the economic system, the armed forces and political parties. After analyzing each, Delgado states that, in general, all of these mechanisms are selective and exclusive, and that movement from one social position to another is not very significant-in other words, the distance from one position to another does not assume a considerable margin. He therefore contends that lower classes remain excluded from channels of upward social mobility. He believes that this could be changing, however, because of waves of migration to the capital, which assumes new opportunities for development in the urban environment. Nevertheless, Delgado concludes that only through the educational system, which creates an opportunity for employment, is it possible to climb the social ladder.

In the 1980s, Luis Muelle (1982) conducted another study on this topic. He highlighted the lack of studies linking social mobility to education, a variable he considered crucial, as it has always been seen as the great hope for attaining social equality. Based on a survey conducted by the Ministry of Labor in the 1970s, Muelle found that a higher level of education did not necessarily imply better employment opportunities. He therefore believed that education alone did not determine a person's wage, but that other criteria, including age, employment and social origin, had to be considered.

More studies of social mobility have been conducted in our country in recent years, and from an economic standpoint. One is by economist Javier Herrera (1999), who uses data from the 
Encuesta Nacional de Niveles de Vida (National Standard of Living Survey. ENNIV, for its initials in Spanish) to try to explain economic mobility during the country's various phases of growth and economic policies. The main conclusion of his study is that neither households below the poverty line nor those above it were the same in 1990, 1994, and 1996. This means that there is a dynamic of upward and downward mobility among the non-poor and the poor that shows considerable heterogeneity. The econometric model that Herrera uses in his study also shows that household composition, possession of assets and level of education are factors that largely determine entry into and exit from poverty.

From a sociological standpoint, the most recent works on this topic are those of Martín Benavides. In one of them (Benavides 2004), the author addresses the topic of education and its influence on job opportunities. He analyzes the relationship among social origin, access to higher education and social mobility. He bases his study on data from the 2000 ENNIV and a supplement to that survey, which includes the parents' situation, focusing on urban males over age 65 and under age 25 (some 1,600 in all). With this information the author builds contingency tables (based on loglinear models) showing information about class of origin, destination and education. The results of the study show that education plays an important role in mobility patterns for men with a higher education, increasing the likelihood of upward mobility and decreasing the chance of downward mobility.

One study that addresses education was carried out by Fanni Muñoz and Mauricio Flores (2007) in Huancavelica. They analyzed the case of the Dirección Regional de Educación (Regional Education Office. DRE, for its initials in Spanish) of Huancavelica to investigate the characteristics of social mobility in that office, the functionaries who obtained jobs there, and factors affecting promotions or demotions. They conducted four in-depth interviews with DRE employees to understand their perceptions of their functions and status. According to Muñoz and Flores, there is an upward social mobility in Huancavelica that is reflected in the lives of these functionaries, because although their parents did not complete primary school - or had no education - these people received a higher education. Intra-generational mobility was also reflected in the promotions the DRE functionaries received throughout their careers. The authors note, however, that although these functionaries have a higher status than the rest of the population, there is income inequality in the region. Finally, the functionaries interviewed are aware of their own limitations and know that they are not yet prepared to compete on equal terms with other professionals from urban areas.

Another study by Martín Benavides (2002), based on a sample of urban workers, shows that relative mobility between groups has been jeopardized by political, economic and cultural factors, and that as a result, social mobility between the extremes is almost non-existent, while there is considerable dynamism in the intermediate zones. According to Benavides, this means that structural changes have occurred in the intermediate bands, causing, in his words, an "expansion of the middle classes," which consist of groups whose origins lie in both the middle and lower sectors (upward social mobility) and in upper sectors (downward social mobility).

Juan La Cruz (2010) analyzed the identities and lifestyles of adults and young people in two families from Unicachi (Puno), who were living in Lima and experiencing upward social mobility. He examined whether the children maintained the economic and cultural practice of migrants from Unicachi, or whether, on the contrary, that practice tended to disappear. This thesis shows that after upward social mobility occurs, there is a tendency toward cultural continuity between parents and children. This process is reflected in the formation of cultural spaces in Lima that are connected with Unicachi and the Aymara culture. This also reinforces the tendency for younger generations to continue businesses started by their parents and to facilitate, as La Cruz puts it, "the material and symbolic reproduction of this Aymara population in the city of Lima."

Silvia Espinal (2010) studied upward social mobility strategies in a case study based on the life stories of five successful families in Lima's Los Olivos district. The purpose of her thesis was to understand the basic collective supporting strategies - reflected in the support of "trunk" families and the re-creation of Andean values and practices - and individualist strategies in the younger generations, which mainly center on personal progress and development. The thesis shows that social mobility involves both strategies, depending on the macro-social periods experienced by the families, which facilitate upward social mobility in some cases and limit it in others. Although the "communal" remains the basis of social mobility, therefore, individualist strategies - and with them, new generations - play a greater role in the long run.

Finally, Roxana Barrantes, Jorge Morel, and Edgar Ventura (2012) analyzed a national survey of perceptions of social mobility among Peruvians. After interpreting these perceptions, organized in various dimensions, such as education, employment, household assets and social capital, the authors conclude that Peruvians are optimistic about social mobility, as in certain dimensions, such as education or possession of goods, that propensity is evident.

From the first writings of Carlos Delgado to the most recent studies of the topic, social mobility has been addressed from a structural standpoint, given the changes the country has experienced and their positive or negative repercussions on individuals' opportunities for climbing the social ladder, considering, in many cases, the families' cultural framework. These works reflect the 
concerns of classical paradigms, but take into account the characteristics of each context. It is along this line that we will present the main findings of this study, organized in six dimensions of analysis: migration and territorial mobility, education, occupation and income, social capital, vulnerability and expectations. The first three involve "hard" information about mobility, while the rest are analyzed from a qualitative standpoint.

\section{Findings and Discussion}

\section{Migration and Territorial Mobility}

One factor that determines "successful" social mobility is human displacement toward territories that offer more and better opportunities for development. This migration has traditionally been considered in two ways. On the one hand are the changes of subjects' places of residence in relation to the place where their parents live, and on the other, migration from the countryside to the city or from a small city to a large one.

In reconstructing the fellows' migratory history, however, it is possible to identify at least two additional elements: their territorial mobility occurs in the same department from which they come; and the return to the country by those who have studied abroad assumes a return to their places of origin. Let us examine this in detail.

Of the fellows who remained to study and work in the regions where they were born, the majority ( 87 percent) moved around within their own regions. Of those who never left the region, 63 percent also did not change province. Of the latter, 58 percent did not even change district. Therefore, more than half of the fellows studied in the department where they were born. Similarly, 62 percent of the fellows lived in the place where they were born, at least until they were selected for the fellowships. Regarding the fellows' return to the country after studying abroad, 81 percent of them, a significant percentage, returned. Sixty-seven percent of them specifically, returned to their place of origin. It is crucial to mention that the IFP signs no formal return commitment with the fellows. We would highlight, however, that nearly seven out of every 10 fellows return not only to the country, but also to their place of origin (IFP 2012).

In short, the migratory pattern described shows that although the fellows were in an "advantageous" place (for example, in regional capitals where there are universities) compared to the places where they lived before receiving the fellowship, there is a tendency to return, including to the district where they were born and/or where they worked before.
Look, I could have stayed in Lima, or even in Puno. But what was I going to do there? How could I help my community from Puno or Lima? No, I chose to return to my community. That's where the fellowship was going to make sense. I am still here, and my school has improved. (E-13)

The sense of belonging to their regions appears to be greater than the temptation to remain in Lima or, less likely yet, abroad. Fellows view the fellowship as an opportunity to benefit themselves, but also to help their communities.

\section{Education}

The influence [of studies] is really strong.... There's a powerful influence on the entire family, even the maid, the girl who works in my house. (E-12)

The fellows received their basic education in public schools, and, with few exceptions, their higher education in a public university. Ninety-eight percent of them paid for their studies themselves, and 70 percent received support from their families, either the nuclear family (minimal economic assistance) or the extended family (housing and non-cash support). This family and individual effort has made about 68 percent of the fellows the first professionals in their families and, in some cases, in their entire communities.

None of the relatives, the cousins, etc., only a few finished secondary school, and many only went to primary school, second or third grade, mainly the women, who came back pregnant or with a family. I was lucky to go on to secondary school, to study at the Normal School and earn a professional degree, which was such a big thing for the community at the time, because it was an extremely important achievement for the village. It was also a milestone here, in my community, that I had the good fortune to be the first professional with an education degree in my village. (E-03)

This context was conducive to inter-generational educational mobility. As Figure 1 shows, most of the fellows' parents, particularly their mothers, did not finish school or completed only a minimal level.

In that sense, educational mobility is manifest. Nevertheless, there are other "data" that offer information about the impact of education on the families, which, although they cannot be considered hard factors associated with social mobility, contribute qualitatively to family welfare. 
He [the brother] has often told me: "Your doctorate has helped you... maybe... it has helped me more than it has helped you." He tells me this because we constantly have this discussion
[...] on various occasions, he has repeated... "Your doctorate has helped me as much as or more than it has helped you. (E07)

Figure 1. Parents' Level of Formal Schooling

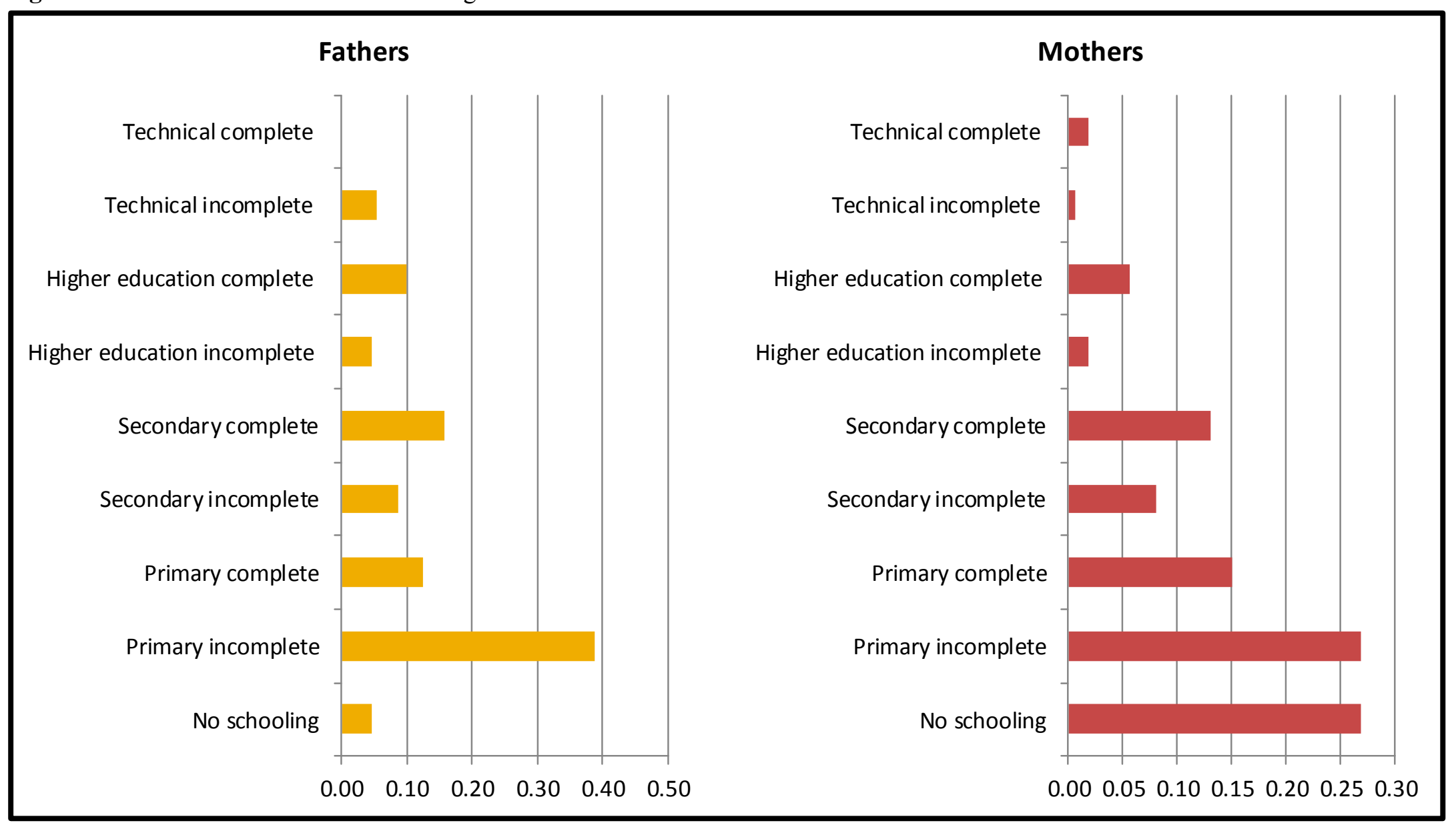

Source: International Fellowship Program-Ford Foundation (2012).

The level of education reached by one family member therefore has an impact on the family dynamic and contributes in some way to a sense of betterment among the other members of the family.

\section{Occupation and Income}

As in the case of education, the fellows' employment and income are better than those of their parents. As Figure 2 shows, most parents are peasant farmers, followed by salaried employees and laborers.

Despite this improvement in employment, compared to their parents' situation, the fellows enter the job market with some disadvantages.
I'll be honest with you - that's another reason why I want to leave here. It seems unfair, with the specialized studies I've done and 17 or 18 years of professional experience, to be at the same level as a colleague who has no specialized studies and four years of professional experience, and that we're both at the same level, both economically and in decision making. It makes me uncomfortable, you know? It annoys me, to tell the truth. I don't like it. (E-05)

When they applied for the fellowship, most of the fellows were under contract in different places. About 40 percent were working in a government agency and about 30 percent in projects run by local NGOs. This situation not only has not changed (the percentages remain almost the same), but their salaries also have not in- 
creased much. In fact, they have changed occupational category compared to their parents - they are employees, rather than peasant farmers - but their incomes have held steady, with little variation, according the information they provide.

I earn less than a male colleague who is engineer like me. I mean, I earn a decent income, but he earns more. And I say that ... what would it be like if I hadn't gotten the Master's degree?
I sometimes think I will earn less because I am a woman. (E08)

Nevertheless, men's incomes have risen more than those of women, for whom it appears more difficult to overcome socio-cultural and economic barriers. All indications are that being poor, indigenous and female remain a difficult disadvantage to surmount.

Figure 2. Occupation of Fellows and Their Parents

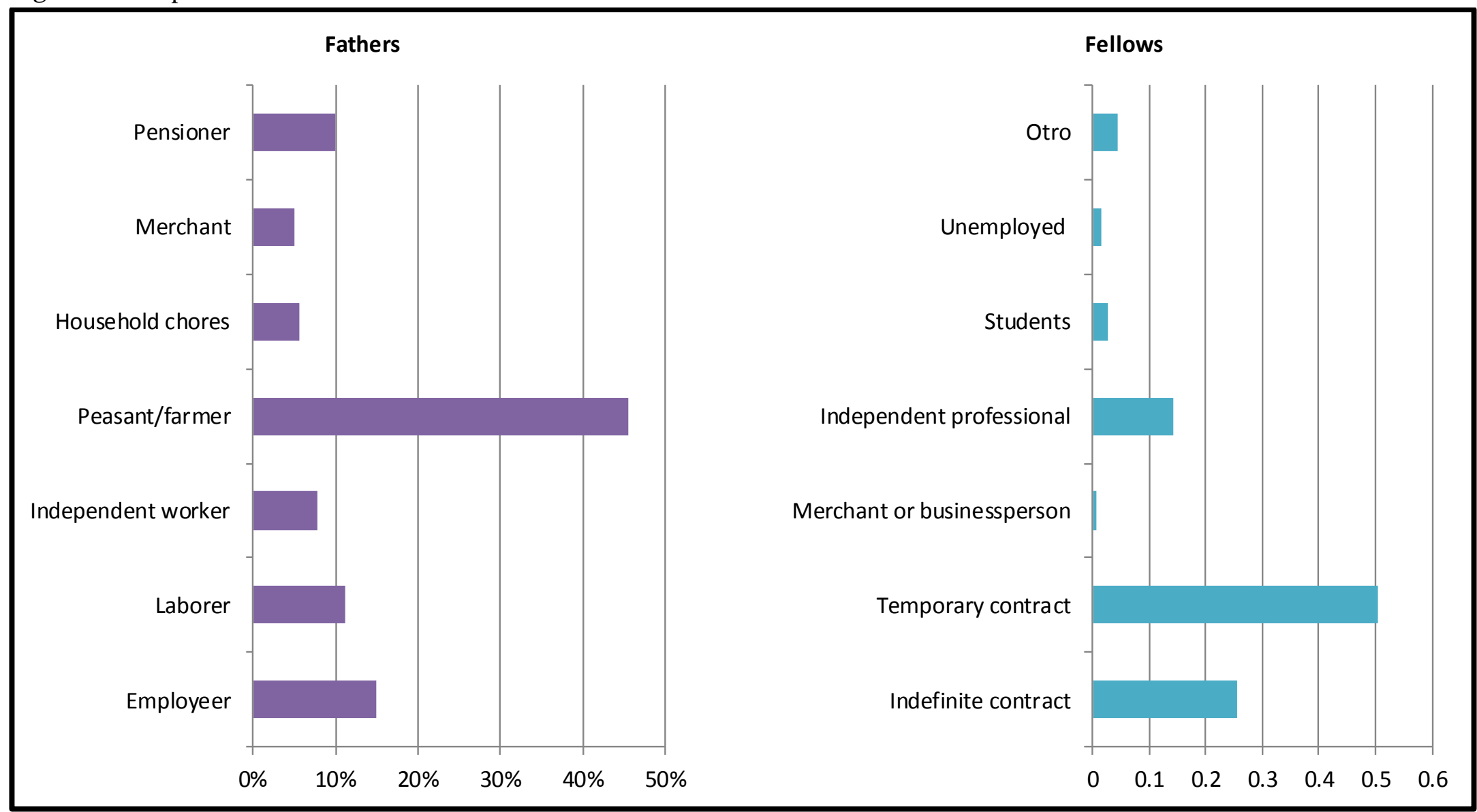

Source: International Fellowship Program—Ford Foundation (2012).

\section{Social Capital}

Social capital - like the following dimensions of vulnerability, satisfaction with the present and expectations of the future-is particularly important, as it supplements the "hard" information provided by the factors described above, offering further elements for in-depth analysis. For the Ford fellows, social capital is a valuable good. Its value even surpasses that placed on income and job stability.
Without our family, without friends, without colleagues, things would be more difficult . . . . I could be somewhere else, but I would lose all my support. (E-11)

As we found in the focus groups with "included" professionals, social capital is a key element in the process of incorporation into the labor market and in strategies for professional growth (GFNE 01, 02, 03). Although the fellows share this perception ("This last job is the one that has allowed me to see that someone who has contacts but no knowledge has thousands more opportunities than 
someone who has knowledge but no contacts" [E-10]), in this case, social capital takes on a value with particular characteristics.

On the one hand, there is a clear association with the idea of expanded extended family, which includes people from the same geographic area, which becomes the social capital mainstay for addressing any eventuality. On the other, the strong community commitment and the tendency to maintain interpersonal networks become matters that the fellows protect, even over and above the individual advantages that they could obtain in a particular job.

I was going to come to Lima. They offered me a job in a ministry. Well paid and everything. But if I left the university [in the person's home region], I would lose everything: my trips to seminars with other fellows, my contacts. You can't imagine how we continue to be a family after the fellowship ends. (E01)

In considering social mobility, the collectivist orientation of excluded professionals translates into their professional development being viewed in terms of the benefit to the community. This is related to a developed sense of social consciousness and, in many cases, to the Andean principle of reciprocity.

\section{Vulnerability}

Among the fellowship application requirements, each fellow discussed his or her ideas about the factors that made him or her vulnerable. ${ }^{1}$ Figure 3 shows the categories of vulnerability that most affected the fellows' lives. The main ones are class (79 percent) and ethnic group (56 percent).

Even when the main reason for vulnerability is economic, it is important not to gloss over ethnic group. Almost half the fellows can be identified as indigenous, based on the variable of native language. This figure coincides with the percentage of fellows who have felt themselves affected by ethnic issues-in other words, all of the indigenous fellows have felt themselves vulnerable, particularly given that the data show that there is a percentage (although smaller) of fellows whose first language is Spanish, who say they have felt themselves to be the targets of discrimination on ethnic grounds. Besides ethnic group, the problem is also racial.

At first, going to Mexico was difficult. Like it was when I first came to Lima. They saw me as an Indian, without believing that I had gone to university. (E-06)

Despite the difficulties, the fellows acknowledge that their higher education has somehow enabled them to reduce the impact of discrimination, particularly in the world of work.
I believe there is still some exclusion, but I think I have made more progress in inclusion. I believe that studies and grades have allowed me to enter this urban world, this more Spanishspeaking world, for me to enter it and to perform well in that world. (E-02)

But perhaps the most complex aspect in the fellows' lives, in terms of vulnerability, is the constant tension in which they live, a tension between maintaining their "relative" stability and the constant possibility of losing it. This is a state that is reproduced in the decisions they make about their place of residence, after finishing their studies, their workplace and their own identity: the risk of "no longer being oneself." We found extreme rhetoric on this subject. Some opted for: "I decided to stay in Lima. I dyed my hair and bought a station wagon and now I have [a good job]" (E-15), while others decided: "Why should I go to Lima? Everything is always more difficult there. It's better for me to stay in my community, working like the community member I am" (E-06).

\section{Expectations}

The fellows have dreams for the future. They do not stop "looking back." They recognize that their situation is much better than that of their parents, and even knowing that it is not "easy," the comparison with the past enables them to construct an optimistic discourse about the life their children will have. Everything the fellows have attained so far, they see as being for their children.

Liliana is a little girl who now studies French, for example, she studies English, she studies in school almost all day, because the idea is to prepare her so she can continue her studies. ... I don't know if she'll get a bachelor's degree or a Master's, but abroad, no? If it's ... a bachelor's degree, I would love for her to be able to study, say, in Canada, and I think that's what we're working toward, so we'll have the resources to do that, no? (E-12)

Nevertheless, the fellows do not abandon the idea of continuing to improve their job possibilities, without giving up the forms characteristic of their own history of exclusion-in other words, based on collective action and leveraging the "community effect" that has been a constant support for them, and for which they work.

I: What else do you think you need? What can you do in the future to...? 
F: Relationships, relationships, basic, basic, see how to enhance my networks, which was an issue we talked about in Ford. What networking means, but it wasn't as academic as they made it look? (E-10)

What probably stands out most is that in this construction of the future, any chink is a huge window of opportunity. Because the fellows see education as the only hope for the future, having had to overcome so many difficulties in that area has given them an urgent need to take advantage of every educational opportunity that appears.
You take advantage of everything you can. I have applied for and won fellowships in the Agrarian University, in genetic improvement, then in CONCYTEC (Consejo Nacional de Ciencia y Tecnología: National Council on Science and Technology] and later the Ford fellowship, which has been a wonderful experience. Whenever a window opens, you have to take advantage. (GFE-01)

The fellows have thus become fighters who seek academic excellence that gives them access to other educational opportunities (fellowships); mainly, however, they have become the force that drives their own inclusion in society.

Figure 3. Categories of Vulnerability

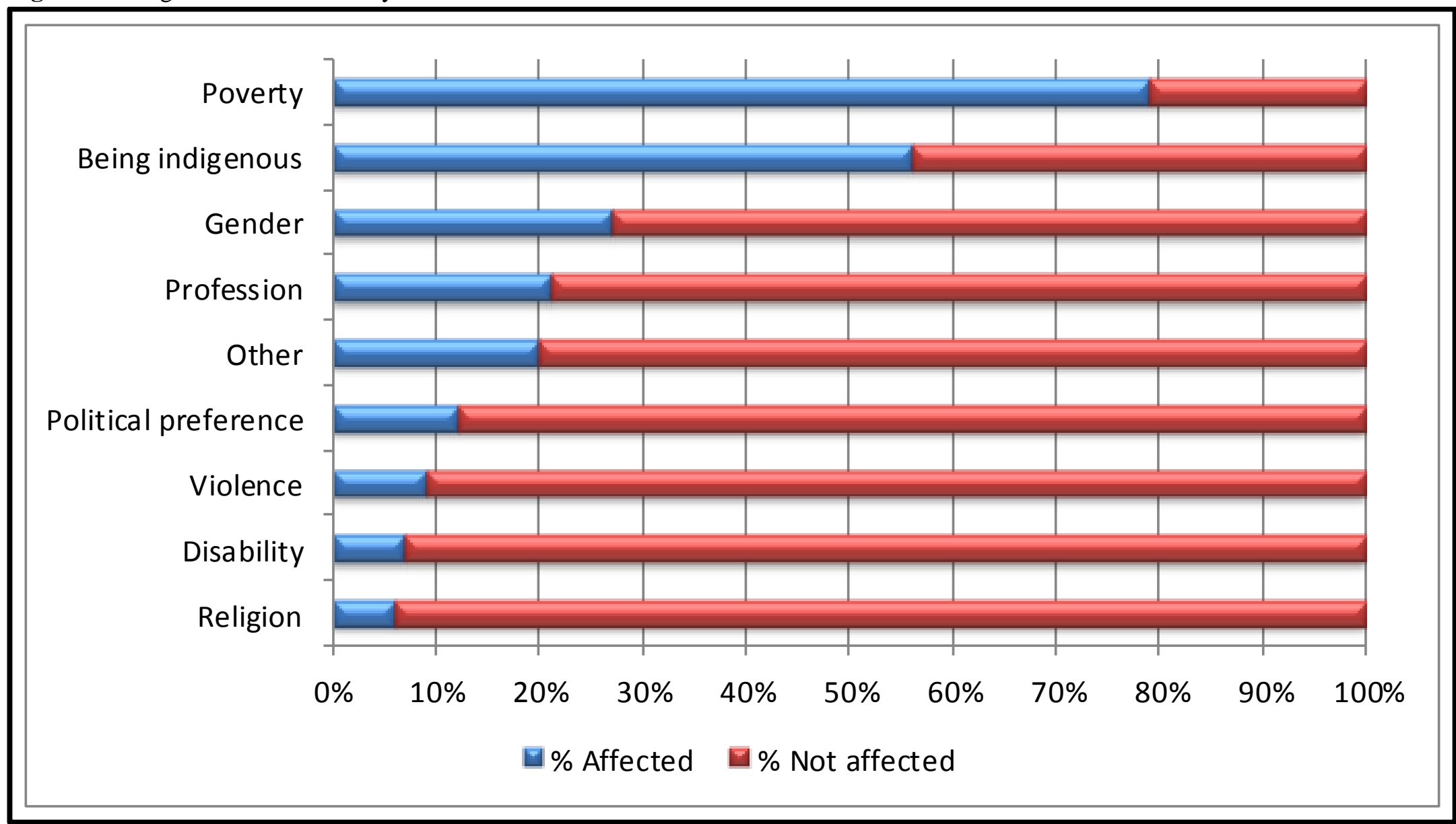

Source: International Fellowship Program-Ford Foundation (2012). 


\section{Conclusions}

The central question posed in this article was whether a group of professionals self-identified as excluded could overcome that state after formal graduate education. After analyzing the ways in which these people experience social mobility and social inclusion, we have shared some initial responses, which unquestionably also raise new working hypotheses.

\section{Social Mobility and Social Inclusion are Heterogeneous Processes}

For the professionals who participated in the study, social mobility and social inclusion are heterogeneous experiences. All indications are that it is possible to climb socially in the current context of the country, but it is also possible to remain in a state of exclusion. Social mobility is not automatically "triggered" by education or a better job. The process of inclusion in other social groups assumes that they develop a strategy that allows them to travel complex routes plagued by barriers, especially cultural ones.

These statements must be understood within a particular framework in which social inequalities take on complex forms that include economic, political and cultural elements (Fraser 2008), but are also characterized by permanent changes - what Fitoussi and Rosanvallon called "dynamic inequalities." "New inequalities, produced by the reassessment of differences within categories previously considered homogeneous, thus began to appear" (Fitoussi and Rosanvallon 1997, p. 74).

This study therefore highlights the need for social mobility indicators that are more and better contextualized in the situation of exclusion. Traditional (and hard) indicators of social mobility and social inclusion appear not to fairly reflect processes followed by subaltern or traditionally excluded groups. Mobility and inclusion are not activated as an automatic result of a series of personal skills and efforts that act in a "perfectly meritocratic" way." On the contrary, they demand particular and specific efforts.

There is a common denominator among all of us. We are people who have overcome difficulties. We have been able to face them and not lose track of where we wanted to go. Each in his or her own way, but that's what we've done. (GFE-01).

Where clear levels of inter-generational upward social mobility have been evident, the fellows' place in the social structure has not changed significantly. In it, the concept of social fluidity is a useful framework for interpretation, because it sees the phenomenon of heterogeneity as key for understanding social stratification, unlike traditional theories, which do not provide an in-depth understanding of this heterogeneity (Baudrillard 1983).

\section{Education Remains a Means of Mobility and Inclusion}

For subaltern young adults, access to higher education is accompanied by a series of positive aspects, not only for the student, but also for his or her family and, in some cases, for the community. Understanding success from the fellows' standpoint means questioning conceptions. As we have seen in focus groups and interviews, the difference lies in the variety of conceptions.

One of the things that made me happiest when I returned from the fellowship was returning to my community and doing the project for the secondary school there. Now I am a little frustrated, because I haven't managed to establish the school here, in Lima, for people who come from my home area. That's what's lacking for me to be completely happy after the fellowship. (E-09)

According to the conclusions of studies of social mobility in Peru, education is a factor that launches a process of social mobility. Although Yamada (2007) maintains that the type of institution of higher education - private and university, more than public and technical-determines the rates of return on higher education, for most of the fellows, all of whom had a public-education background, more advanced studies have led to a better standard of living.

This should therefore revive discussion about what Fidel Tubino called the "myth of higher education." This myth has taken root in the imaginary of the most disadvantaged people as a way of improving their lives, at times when having a basic education has begun to be perceived as inadequate for achieving the desired opportunities. Despite arguments by Zavala and Córdova (2011) that this myth has not been able to expand, because still only a minority of the excluded population can gain access to higher education, there is the idea, from a particular standpoint, that for the poorest people, higher education is governed by a set of pre-established rules. For example, professionals who do not belong to traditionally excluded groups maintain that the success of a higher education depends on the career a person chooses y and how early the person begins. That career does not end until the person has achieved considerable material comfort, a point perceived as "success." The idea is not to have economic constraints, to minimize "sacrifice" (lack of things), ensure an economic stability that allows better opportunities for the person and his or her family, and raise their status. This group believes that these variables will lead to a happy life (GFNE-01, 02, 03).

Tubino (2007) maintains, correctly, that the myth of higher education creates dreams, but also frustrations. That disenchantment, however, does not correlate with the perception of success. The 
fellows do not stop believing that they have new goals, and that achieving them is, in itself, a success, and they project that sense of achievement based on having overcome the constraints they have faced in their lives and on having continued to fight. It is therefore worth asking: Whose myth is the myth of higher education? From what standpoint is it understood to be a myth?

\section{Social Mobility Coexists with Inequality}

Even when the class system assumes a scenario that allows one to "move" from one social stratum to another (Giddens 2002), the stratification reveals the structural inequalities that exist between different groups of people. We could say that traditionally excluded professionals have climbed socially, that they have "surpassed" their parents, but that there has been no substantive change in their state of inequality.

[With some friends] we have thought that we continue to be excluded, and that we cannot attain certain positions, because it seems that they view us as having certain deficiencies. I seem to be at that level. (E-11)

As Plaza (2007) notes, social classes are defined by their place in the productive process, but that does not exhaust the definition, because the cultural dimension also plays a very important role. What is described above refers to individuals' social practices. For that reason, class structure is said to be not a self-regulated mechanism, but "a social process and product, originated and reproduced by the way in which the organization of society determines access to tangible and non-tangible resources, and by the actions and social practices of the actors" (p. 66). After analyzing the fellows' lives after their studies, one can conclude, as Nunn and colleagues (2207) state, that social mobility is more an individual than a social experience.

All of the interviewees agree that inclusion is not a goal that is achieved. Rather, it is an ongoing way of relating to one's social environment. The first and most direct responsibility, therefore, is to seek to insert oneself into society and the world of work. This task assumes a constant battle to overcome the initial obstacles.

\section{Mobility and Social Inclusion Require Broader Concepts}

Of course you feel excluded, but after the experience with the Ford fellowship, I feel different, somehow also more included, more integrated, part of a group of people with whom I share a great deal. When we get in touch with each other, we're like a family. (GFE-01)
Based on the information reviewed, we propose a broader conception of social mobility, because of the difficulty of understanding this process in people with particular characteristics. Although the literature on the subject recognizes more relative forms of mobility than the traditional, structural ones, our analysis shows that even those relative forms are an inadequate framework for understanding the complex process of movement from one social level to another.

Our call to broaden the conception of social mobility and social inclusion presupposes placing greater importance on symbolic factors that allow better contextualization of the process. Following Méndez and Gayo (2007), studies of social stratification and social mobility are governed by two different visions. The first sees society as a group of individuals with different occupations, tastes, lifestyles, etcetera, which causes them to have different ways of thinking and acting. The second vision emphasizes people's life histories, implying that class formation would be more a process than a permanent structure. The authors note that the latter would not reveal greater dynamism in society, but would reflect the existence of a series of movements that its members could make based on individual experience. Studies of social mobility would thus fall into this latter perspective, since, as we have noted, this process emerges as one that creates societies "open" to change.

\section{Acknowledgements}

I would like to thank Rodrigo Niño, who worked with me throughout this study, and Silvia Espinal, who helped with the review and bibliography. Thanks also to Emilio Gautier and Natallia González for their preliminary comments and ongoing discussion. Special thanks to each of the fellows of the Ford Foundation International Fellowships Program, who gave meaning to our hypotheses and readings.

\section{Note}

1. For a more in-depth discussion of this topic, see Virginia Zavala and Nino Bariola as referenced in Cuenca (2012).

\section{References}

Atria, Raúl, ed. 2007. Estratificación y movilidad social en América Latina, transformaciones estructurales de un cuarto de siglo [Stratification and Social Mobility in Latin America, Structural 
Transformations of a Quarter of a Century]. Santiago, Chile: LOM Editores.

Barrantes, Roxana, Jorge Morel, and Edgar Ventura. 2012. El Perú avanza o los peruanos avanzamos? El estado actual de la movilidad social en el Perú [Does Peru Advance or Do We Peruvians Advance? The Actual Estate of Social Mobility in Pe$r u$ ]. Lima: Instituto de Estudios Peruanos.

Baudrillard, Jean. 1983. Las estrategias fatales [The Fatal Strategies]. Barcelona: Anagrama.

Benavides, Martín. 2002. "Cuando los extremos no se encuentran: un análisis de la movilidad social e igualdad de oportunidades en el Perú contemporáneo a partir de una muestra de trabajadores urbanos [When the Extremes Don't Meet: An Analysis of Social Mobility and Equality of Opportunity in Contemporary Peru from A Sample of Urban Workers]." Boletín del Instituto Francés de Estudios Andinos.

Benavides, Martín. 2004. "Educación y estructura social en el Perú. Un estudio acerca del acceso a la educación superior y la movilidad intergeneracional en una muestra de trabajadores urbanos" ["Education and Social Structure in Peru. A Study about Access to Higher Education and Intergenerational Mobility by a Sample of Urban Workers"]. In Es posible mejorar la educación peruana? Evidencias y posibilidades [Is It Possible to Improve Peruvian Education? Evidence and Possibilities], ed. Patricia Arregui. Lima: Grade.

Blau, Peter M., and Otis D. Duncan. 1967. The American Occupational Structure. New York: Wiley.

Conconi, Adriana, Guillermo Cruces, Sergio Oliveri, and Raúl Sánchez. 2008. "E pur si muove: movilidad, pobreza y desigualdad en América Latina" ["And Yet It Moves: Mobility, Poverty and Inequality in Latin America"]. Revista Económica La Plata LIV (1-2), 121-159.

Cotler, Julio, and Ricardo Cuenca, eds. 2011. Las desigualdades en el Perú. Balances críticos [The Inequalities in Peru. Critical Balances]. Lima: Instituto de Estudios Peruanos.

Crompton, Rosemary. 1994. Clase y estratificación: una introducción a los debates actuales [Class and Stratification: An Introduction to Actual Debates]. Madrid: Tecnos.

Cuenca, Ricardo, ed. 2012. Educación superior, identidad y movilidad social. Lima: Instituto de Estudios Peruanos.

Cuenca, Ricardo, and Rodrigo Niño. 2011. Igualando oportunidades. Sistematización del Programa Internacional de Becas de la Fundación Ford en el Perú [Making Opportunities Even. Systematization of the International Program of Scholarships of the Ford Foundation in Peru]. Lima: Instituto de Estudios Peruanos.

Delgado, Carlos. 1967. Notas sobre la movilidad social en el Perú [Notes on Social Mobility in Peru]. Lima: Instituto de Estudios Peruanos.

Espinal, Silvia. 2010. "Ahora somos de clase media: estrategias de movilidad social ascendente en cinco familias exitosas del distrito de Los Olivos" ["Now We Are from the Middle Class: Strategies of Ascendant Social Mobility in Five Successful Families from the Los Olivos District"]. Licentiate Thesis in
Social Sciences with Concentration in Sociology. Lima: Pontificia Universidad Católica del Perú.

Fitoussi, Jean, and Pierre Rosanvallon. 1997. La nueva era de las desigualdades [The New Era of Inequality]. Buenos Aires: Ediciones Manantial.

Fraser, Nancy. 2008. Escalas de justicia [Scales of Justice]. Barcelona: Herder.

Giddens, Anthony. 2002. Sociología [Sociology]. Madrid: Alianza Editorial.

Glass, Ruth. 1963. Introduction to London: Aspects of Change. London: Centre for Urban Studies.

Goldthorpe, John H., Catriona Llewellyn, and Clive Payne. 1980. Social Mobility and Class Structure in Modern Britain. Oxford: Clarendon Press.

Herrera, Javier. 1999. "Ajuste económico, desigualdad y movilidad" ["Economic Adjustment, Inequality and Mobility"]. In Pobreza y economía social: análisis de una encuesta [Poverty and Social Economy: Analysis of a Poll], ed. Richard Webb, ENNIV 1997. Lima: Instituto Cuánto.

La Cruz, Juan. 2010. "Unicachi: el rugido aymara continúa? Movilidad social ascendente y cambio sociocultural en familias migrantes de unicachinos en Lima" ["Unicachi: the Aymara Roar Continues? Ascendant Social Mobility and Sociocultural Change in Migrant Families of Unicachinos in Lima"]. Licentiate Thesis in Social Sciences with Concentration in Sociology. Lima: Pontificia Universidad Católica del Perú.

León, Janina, and Javier Iguiñiz, eds. 2011. Desigualdad distributiva en el Perú: dimensiones [Distributive Inequality in Peru: Dimensions]. Lima: Pontificia Universidad Católica del Perú.

Lipset, Seymour M., and Reinhard Bendix. 1959. Social Mobility in Industrial Society. Berkeley: University of California Press.

Méndez, Maria L., and Modesto Gayo. 2007. "El perfil de un debate: movilidad y meritocracia. Contribución al estudio de las sociedades latinoamericanas" ["The Profile of a Debate: Mobility and Meritocracy. Contribution to the Study of Latin American Societies"]. In Estratificación y movilidad social en América Latina, transformaciones estructurales de un cuarto de siglo [Stratification and Social Mobility in Latin America, Structural Transformations of A Quarter of A Century], coordinated by Raúl Atria. Santiago de Chile: LOM Editores.

Muelle, Luis. 1982. Movilidad social, educación e ingresos en áreas urbanas del Perú [Social Mobility, Education, and Income in Urban Areas of Peru]. Lima: Instituto de Investigación y Desarrollo Educativo.

Muñoz, Fanni, and Mauricio Flores, 2007. "Notas para el estudio de la movilidad social y estratificación en el Perú: el caso de los funcionarios públicos del sector educación a nivel regional" ["Notes for the Study of Social Mobility and Stratification in Peru: the Case of Public Officials from the Education Sector at Regional Level"]. In Clases sociales en el Perú: visiones y trayectorias, ed. Orlando Plaza. Lima: Pontificia Universidad Católica del Perú.

Nunn, Alex. 2007. Factors Influencing Social Mobility. Leeds: Corporate Document Services. West Yorkshire, UK: Leeds 
Metropolitan University and the Department of Works and Pensions.

Plaza, Orlando. 2007. "El debate teórico sobre las clases sociales: una aproximación histórico-analítica" ["The Theoretical Debate on Social Classes: A Historical-Analytical Approximation"]. In Clases sociales en el Perú: visiones y trayectorias [Social Classes in Peru: Visions and Trajectories], ed. Orlando Plaza. Lima: Pontificia Universidad Católica del PerúCISEPA.

Sanborn, Cynthia, and Alonso Arrieta. 2011. Universidad y acción afirmativa: balance y agenda pendiente [University and Affirmative Action: Balance and Pending Agenda]. Lima: Centro de Investigaciones de la Universidad del Pacífico.

Thorp, Rosemary, and Maritza Paredes. 2011. La etnicidad y la persistencia de la desigualdad: El caso peruano [Ethnicity and the Persistence of Inequality: the Case of Peru]. Lima: Instituto de Estudios Peruanos.

Tubino, Fidel. 2007. "Las ambivalencias de las acciones afirmativas." In Educar en ciudadanía intercultural. Experiencias y retos en la formación de estudiantes universitarios indígenas [Experiences and Challenges in the Formation of Indigenous University Students], ed. Juan Ansión and Fidel Tubino. Lima: Pontificia Universidad Católica del Perú.

Yamada, Gustavo. 2007. Retornos a la educación superior en el mercado laboral: vale la pena el esfuerzo? [Return to Higher Education in the Labor Market: Is It Worth the Effort?] Lima: Universidad del Pacífico - Consorcio de Investigación Económica y Social.

Zavala, Virginia, and Gavina Córdova. 2010. Decir y callar: Lenguaje, equidad y poder en la universidad peruana. [To Say and to Shut Up: Language, Equity, and Power in the Peruvian University]. Lima: Pontificia Universidad Católica del Perú. 